substrate amounts and their accumulation is a direct measure of the photosynthetic process. Here photosynthesis may be considered as having been completed before carbon assimilation begins. The key problem of photosynthesis, the conversion of light into useful chemical energy, need not, therefore, be enmeshed in the dark enzymatic reactions responsible for the synthesis of carbohydrates.

We are indebted to Dr. F. R. Whatley for the preparation of chloroplasts. We were aided in this investigation by grants from the U.S. Public Health Service and the Office of Naval Research.

1 Blackman, F. F., Ann. Bot., 19, 281 (1905)

${ }^{2}$ Warburg, O., Biochem. Z., 100, 230 (1919).

${ }^{3}$ Rabinowitch, E. I. " "Photosynthesis and Related Processes", 1, 61 (Interscience, New York, 1945).

${ }^{4}$ Arnon, D. I., Allen, M. B., and Whatley, F. R., Nature, 174, 394 (1954). ${ }^{5}$ Arnon, D. I., Whatley, F. R., and Allen, M. B., J. Amer. Chem. Soc.,

${ }^{6}$ Arnon, D. I., Science, 122, 9 (1955).

${ }^{7}$ Alle n, M. B., Arnon, D. I., Capindale, J. B., Whatley, F. R., and Durham, L. J., J. Amer. Chem. Soc., Yro, 4149 (1955)

${ }^{8}$ Arnon, D. I., Allen, M. B., Whatley, F. R., Capindale, J. B., and Rosenberg, L. L., Proc. 3rd Int. Cong. Biochem., 227 (Brussels 1955 )

'Arnon. D. I., "Enzymes: Units of Biological Structure and Function", edit.' O. H. Gaebler, 279 (Academic Press, New York, 1956)

${ }^{10}$ Arnon, D. I., Allen, M. B., and Whatley, F. R., Biochim. Biophys 1cta, 20, 449 (1956).

${ }^{11}$ Whatley, F. R., Allen, M. B., Rosenberg, I. L., Capindale, J. B., and Ärnon, D. I., Biochim. Biophys. Acta, 20, 462 (1956).

${ }^{12}$ Allen, M. B., Whatley, F. R., and Arnon, D. I., Biochim. Biophys Acta, 27, 16 (1958)

${ }^{13}$ Irmak, L. R., Révue Faculté Sci. de l'Univ. d'Istanbul, B, 20, $237(1955)$.

14 Ueda, R., Botan. Mag. (Tokyo), 62, 731 (1949).

${ }^{15}$ Thomas, J. B., Haans, A. J. M., and Van der Leun, A. A. J., Bio chim. Biophys. Acta, 25, 453 (1957).
${ }^{16}$ Burk, D., and Warburg, O., Z. Naturforsch, 6b, 12 (1951).

${ }^{17}$ Arnon, D. I., "Ann. Rev. Plant Physiol.", 7, 325 (1956).

${ }^{18}$ James, W. O., and Das, V. S., New Phytologist, 56, 325 (1957).

${ }^{19}$ Warburg, 0., Angewandte Chemie, 69, 627 (1957).

${ }^{20}$ Hill, R., Nature, 139, 881 (1937); Symposia Soc. Exp. Biol., 5. 223 (1951).

${ }^{21}$ Arnon, D. I., Whatley, F. R., and Allen, M. B., Science, 127, 1026 (1958).

${ }^{22}$ Vishniac, W., and Ochoa, S., Nature, 187, 768 (1951).

${ }^{23}$ Tolmach, I. J., Nature, 167, 946 (1951).

24 Arnon, D. I., Nature, 167, 1008 (1951).

${ }^{25}$ San Pietro, A., and Lang, H. M., Science, 124, 118 (1956).

${ }^{26}$ Arnon, D. I., Whatley, F. R., and Allen, M. B., Nature, 180, 182 (1957).

${ }^{27}$ San Pietro, A., and Lang, H. M., J. Biol. Chem., 231, 211 (1958).

${ }^{28}$ Arnon, D. I., Whatley, F. R., and Allen, M. B., Biochim. Biophys. Acta (manuscript to be submitted).

Warburg, O., and Christian, W., Biochem. Z., 287, 440 (1936) ; 292 287 (1937).

"Vishniac, W., Horecker, B. L., and Ochoa, S., "Advan. Enzym.", 19, 1 (1957).

${ }^{31}$ Racker, F., Nature, 175,249 (1955).

${ }^{32}$ Racker, F. (personal communication).

${ }^{33}$ Tager, E. W., Arch. Biochem. Biophys., 41, 383 (1952).

${ }^{34}$ Emerson, R., and Arnold, W., J. Gen. Physiol., 16, 191 (1932).

${ }^{35}$ Briggs, G. E., Proc. Roy. Soc., B, 113, 1 (1933).

${ }^{36}$ Briggs, G. E., Biol. Rev., 10, 461. (1935).

3. McAllister, E. D., and Myers, J., Smithson. Misc. Coll. No. 6, 99 $(1940)$.

${ }^{38}$ Hill, R., and Whittingham, C. D., New Phytologist, 52, 133 (1953).

${ }^{3}$ McAllister, E. D., J. Gen. Physiol., 22, 613 (1939).

${ }^{40}$ Aufdemgarten, H., Planta, 29, 643 (1939).

Ruben, S., Kamen, M. D., and Hassid, W. Z., J. Amer. Chem. Soc., 62, 3443 (1940)

"Benson, A., and Calvin, M., Science, 105, 648 (1947).

${ }^{43}$ Calvin, M., and Benson, A. A., Science, 107, 476 (1948).

"Calvin, M., Bassham, J. A., Benson, A. A., Lynch, V. H., Ouellet C., Schou, L., Stepka, W., and Tolbert, N. E., Symposia Soc. Exp. Biol., 5, 284 (1951).

${ }^{45}$ Gatfron, H., Fager, E. W., and Rosenberg, J. L., Symposia soc. Exp. Biol., 5, 263 (1951).

${ }^{46}$ Fuller, R. C., and Anderson, E. C., Plant Physiol. Supp., 32, xvi (1957).

\title{
THE JOHN CURTIN SCHOOL OF MEDICAL RESEARCH, AUSTRALIAN NATIONAL UNIVERSITY
}

$\mathrm{O}$ $\mathrm{N}$ March 27, Sir Howard Florey, in the presence of the Prime Minister of Australia, the Right Hon. R. G. Menzies, opened the new building of the John Curtin School of Medical Research at the Australian National University in Canberra. The National University was founded in 1946 as a national centre for research and research training, initially in the fields of physical sciences, medical sciences, and the social sciences.

There had long been complaints in Australia that many of the most able scientists left the country because of the greater attractions in universities and research institutions in Great Britain. Such complaints applied more to the medical sciences than to other natural sciences, for which the large and varied laboratories of Commonwealth Scientific and Industrial Research Organization provided first-class facilities, whereas the only medical research institute in Australia with an international reputation was the relatively small Walter and Eliza Hall Institute in Melbourne.

In a report to the Commonwealth Government in 1944, Sir Howard Florey suggested that a national institute for advanced medical sciences should be set up in Australia, and the John Curtin School of Medical Research, established as an integral part of a University devoted to research and research training, is the result of this suggestion. Sir Howard Florey was intimately associated with the development of the School from the time of his report until 1955 , and the building he opened on March 27 is a monument to his inspiration and drive. There were no laboratories in Canberra in 1948 when the first professor was appointed, so the departments were started in laboratory space generously lent by several institutions-biochemistry at the Commonwealth Serum Laboratories, Melbourne ; medical chemistry at the Welleome Research Institution in London; microbiology at the Walter and Eliza Hall Institute in Melbourne; experimental pathology in Sir Howard Florey's Laboratories in Oxford and physiology in the University of Otago in New Zealand.

In 1951, temporary laboratories were built in Canberra, and these were occupied between 1952 and 1957, when the departments transferred to the present building (Fig. 1). This is a brick building about 170,000 sq. $\mathrm{ft}$. in floor area. It is built in an $\mathrm{H}$-shape, with four wings for laboratories (which are mainly confined to the upper two floor-levels) and a central spine housing lecture theatre, seminar rooms, offices, tea rooms and library. The lower levels of the building house many of the service departments: store, photography, media kitchens, mechanical plant, etc. In addition, there are two animal houses, each 
N A T U R E

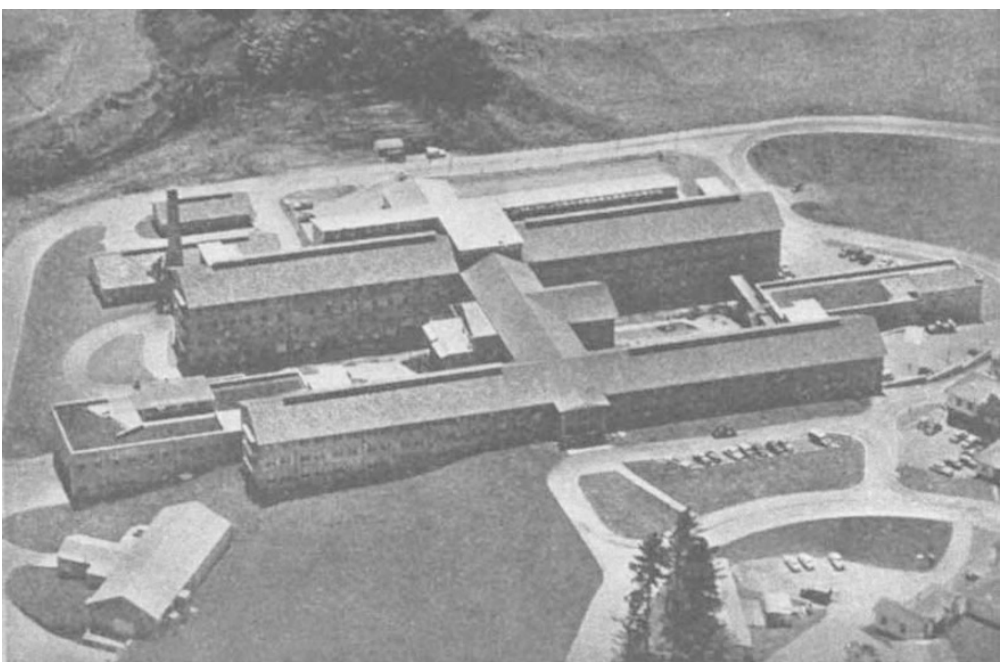

Fig. 1. The John Curtin Schəol of Medical Research, Australian National University, Canberra

of some $7,000 \mathrm{sq}$. ft. floor ares-one for non-infected and the other for infected animals; an animalbreeding establishment some four miles away, and a large light-engineering workshop.

The laboratory wings have on the south side laboratories $20 \mathrm{ft}$. deep and on the north side service rooms (hot rooms, cold rooms, etc.) and studies $14 \mathrm{ft}$. deep. The laboratory layout on each floor-level is adapted to the needs of the particular department, but within the departments it follows a standard plan.

At present there are five departments-biochemistry, experimental pathology, medical chemistry, microbiology and physiology. Prof. A. H. Ennor, head of the Department of Biochemistry, is also dean of the School. His department comprises nine staff

\section{August 9, 1958}

VOL. 182

and five research students, and is concerned principally with enzymology of phosphorylated guanidines. Prof. F. C. Courtice, well known for his researches on physiology of lymph flow, etc., has just been appointed to the chair of experimental pathology. Prof. Adrien Albert heads a group of seven research workers and two research students in the Department of Medical Chemistry. His work on heterocyclic chemistry is familiar to most British scientists, and he now has greatly increased facilities for this work. Prof. F. Fenner, with seven staff members and eight research students, is investigating various aspects of animal virology, principally with the pox viruses and influenza viruses. The Department of Physiology, headed by Prof. J. C. Eccles, specializes in neurophysiology. Prof. Eccles is at present president of the Australian Academy of Science. His distinguished investigations made by micro-electrode methods are widely known, and he is assisted in this work by seven staff members and four research students.

At present the total research staff is about forty and there are some twenty Ph.D. students; but the John Curtin School of Medical Research is still in the process of growth, both in the sense that several new departments will be developed over the next few years to fill in gaps in the present structure, and in the development of each individual department. The new building just opened by Sir Howard Florey provides excellent facilities in a wide range of the medical sciences and already the School is established as a research institution well known throughout the world.

\section{HIGH ENERGY NUCLEAR PHYSICS}

$\mathrm{T}$ THE annual international conference for 1958 on High-Energy Nuclear Physics, which was held in Geneva during June 30-July 5 under the sponsorship of the International Union of Pure and Applied Physics was the successor to those that have been held annually in Rochester, New York, for the past seven years. Over these years the size and duration of the Conference had increased from a small oneday meeting to a full week of intensive sessions recognized as the most important conference on highensrgy physics of the year. It was the general opinion at Rochester in 1957 that the volume of effort and the number of contributions had grown to such an extent that the traditional system whereby each contributor presented the results of his experiments had become unworkable and, short of the undesirable step of limiting the scope of the conference still further, it was evident that some new method of presenting the material had to be tried. This year at the European Centre for Nuclear Research (C.E.R.N.) the conference was divided into ten half-day sessions and all contributions in a particular field were presented to the conference by one person, the rapporteur, whose job it was to introduce the subject and to present and to explain the significance of the results obtained. The talks by the rapporteurs were expected to take up approximately half the session and the other half was left for discussion or for the presentation of special papers which did not fit well into the rapporteur's general scheme. The success of this procedure depends very much on the rapporteur. Contributors were asked to submit their papers to him some four weeks before the plenary sessions. Organizing sessions were arranged on the three days preceding the conference proper to enable participants to meet their rapporteur and if necessary to discuss their contributions with him. As an additional preliminary rapporteurs were asked, prior to the Conference, to provide participants with a reading list which would serve as an introduction to the subjects.

The general opinion at the end of the Conference was that the new method of presentation had been enough of a success for the method to be tried again. It was most successful where the rapporteurs, having been selective in the choice of their material, had leisure to present it in a critical way and not merely as a report of a large number of different experiments. 